\title{
Implementation Of Business Road Map as a Development of Business Model Canvas In The Ruang Temu Café In Samarinda
}

\author{
Riyan Danu Setiawan ${ }^{1} 8$ (D) $\triangle$, Finnah Fourqoniah ${ }^{2}$ (D) and Muhammad Fikry Aransyah ${ }^{3}$ (iD \\ ${ }^{123}$ Faculty of Social and Political Sciences, Mulawarman University, Indonesia \\ $\triangle$ Corresponding Author: Riyan Danu Setiawan, E-mail: Riyandanusetiawan43@gmail.com
}

\author{
ARTICLE INFORMATION \\ Received: July 01, 2021 \\ Accepted: August 12, 2021 \\ Volume: 3 \\ Issue: 2 \\ DOI: 10.32996/jbms.2021.3.2.9
}

\section{KEYWORDS}

Business Model, Business Model

Canvas, Business Road Map,

development

\section{ABSTRACT}

Business actors must understand the importance of a business model in entrepreneurship; a business strategy is needed. There are several business models, but the one most often used by business actors is the Business Model Canvas or what we usually know (BMC). According to several studies, the Business Model Canvas can still be a business model that can still be developed into a more detailed business model and better mapping. Then from the Business Model Canvas, a new business model was developed, namely the Business Road Map, to win the market competition. Business Road Map is a pattern or Business Mapping Method to build a business model/business plan capable of creating growth over time. It was found that there was a significant increase in turnover after implementing the Business Roadmap. The actual Business Road Map is a development of the Business Model Canvas. Compared to other business models, the Business Road Map is considered to be much more detailed in business mapping and can also check the business's growth.

\section{Introduction}

As the provincial capital, the culinary business in Samarinda is quite promising. Many migrants from outside come to Samarinda to become business actors. Most of the immigrants from outside Samarinda opened a business in the culinary field. The culinary business was chosen because the culinary business in Samarinda has a reasonably good and fast turnover, so that the opportunity is considered quite good. Samarinda is considered to be a lucrative market for the sale of food products. Culinary business people, it is proven that they continue to sell their products in Samarinda. Even the culinary business is considered to be able to increase by 20 percent this year. This can be seen from the increase in the culinary business in 2017. Currently, culinary entrepreneurs have dared to make breakthroughs, such as exciting concepts to compete with other businesses.

One of the culinary businesses that are pretty busy is the Café Business. The Café business in Samarinda has a pretty good potential to grow. This is evidenced by the emergence of various cafes with different concepts. Although they have different concepts, each of these cafes has a different market share. Recognizing the character of consumers in starting a cafe business is very important. By knowing and understanding it, researchers can identify suitable business models and run a business to win the market competition.

From the phenomenon of the business model, the researcher assesses that the topic of research on business models is quite interesting to study because it has a considerable influence on the existence of the culinary business. Especially in businesses where the barrier to entry for businesses in Samarinda is quite tight, whereas some small businesses do not last long. This results in the business going bankrupt or closing.

From several research objects Café, the authors take the object of research in the Ruang Temu Café. The author chose the Ruang Temu Café as the object of research because the value and concept offered by the Café were excellent, and not all Cafés had the

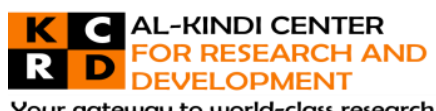

Your gateway to world-class research

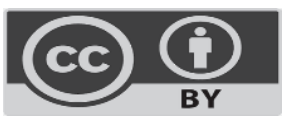

Published by Al-Kindi Center for Research and Development. Copyright (c) the author(s). This open access article is distributed under a Creative Commons Attribution (CC-BY) 4.0 license 
same values and concepts. This cannot be separated from the intervention of the owner of the Ruang Temu Café, which is considered quite good in terms of management and quite good in implementing the required business model strategy.

Business actors must understand the importance of business models in entrepreneurship; a business strategy is needed. There are several business models, but the one most often used by business actors is the Business Model Canvas or what we usually know (BMC). The Business Model Canvas has been widely used by business actors, including at Café Ruang Temu. Before becoming a café, Ruang Temu operated a café, but it did not last long and could not compete with other cafés in Samarinda. However, it is different from the Ruang Temu, which can still survive and maintain its existence until now. Coupled with the covid 19 virus outbreak, it turned out to have a significant impact on the Ruang Temu café business. For almost four months, they had not been operating due to a policy from the government that required it to be closed so that no customers came once. After they closed for four months and did not generate any income at all, that is where they got the idea to upgrade a new business strategy, namely the new Business Model Canvas, in the new average era and make a strategy and get health protocol certification from the health office, ministry of health and governor. One of the strategies they did improve their business mapping concept by using a Business Roadmap that was none other than the development of the Business Model Canvas.

The Business Model Canvas is a tool in management strategy to translate concepts, consumers, infrastructure, and company finances into visual elements. According to Rudi Kevin, Tulus (2016), the study results show that the business model at PT. Joyo Bekti Indah is interrelated with one another. Meranga (2019) TheBusiness Model Canvas appropriate, one-sided social mission, two-sided social mission, market-oriented social mission, and commercially utilized social mission. Saputra and Widjaja (2019) Ecommerce-based online sales help customers get products that suit their needs and assist in the remote ordering process. Sanim et al. (2016) increase the value proposition, customer segment, and customer relations will affect an organization's revenue. Gata and Alpedro (2019), creating an E-commerce website on the Mr. Bro distribution, will increase maximum sales and market coverage.

Sultan and Fatricia (2019) The results show that the nine elements of the Business Canvas Model have a relationship. Tantriana (2018) The results obtained are an overview of the nine elements in the Business Model: Customer Segment, Value Proposition, Customer Relationship, Customer Segment, channels, Revenue Streams, Cost Structure, Key Activities, Key Resources, and Key Partnerships. Chandra (2016) The results show that the company's business model requires several additional factors in each business model element to develop and lead the company towards a better future. Alfarisi, Alfan (2019) The results show that Toyosima should use one of the strategies according to the Unbundling business model, namely Product Innovation. Hubeis, Maulana, et al. (2014) The results of this study indicate that the business model that KN Fish Farm has carried out has found weaknesses in the nine elements of BMC. Therefore improvements are made to all elements. Luthan, Winandi, et al. (2019) The results of the analysis show that the nine elements of the Business Model Canvas indicate that there are internal and external factors that are strengths and weaknesses for the company in carrying out its business model and also what are the opportunities and threats from external that affect PT XYZ's business processes. Pasaribu, Munawir, and Rizka Harfiani (2019) The results show that $\mathrm{CV}$. Media has successfully run a business by implementing nine elements of BMC; this can be seen from the increasing income of the company every year. Magdalena Kosasi, Velicia (2015) From the SWOT analysis results for business model development, the company is advised to develop customer segments for young families with young children and further enhance product innovation. Hidayat, Dayat, et al. (2020) concluded that in making the IPMS implementation scheme, there are five main steps: developing strategies, planning strategies, aligning the organization, implementation, \& monitoring, and learning. Based on the description above, the author is challenged to research the Business Model Canvas and its development using Café Ruang Temu.

\section{Method}

The type of research used is descriptive qualitative. Qualitative research is research that intends to understand the phenomenon of what is experienced by research subjects. This type of research was chosen in order to build an analysis result. The writer took qualitative research to go directly to the object of research to see and observe directly how it was implemented in the field.

The object of research that will be used as a place of research is a café business-qualitative data from primary data sources and secondary data. Primary data was obtained directly by doing so through observation, and interviews were conducted with Cebu Windi as the owner of the Café. Secondary data sources are presented in other forms or other people, namely literature, books, the internet, journals, and theses-this study uses in-depth interviews and observational roles.

The data analysis technique used is data collection, carried out by observation and in-depth interviews; Data Reduction, data obtained from the field is then recorded carefully and in detail; Presentation of data, after the data is reduced, the next step is to 
display the data; and Verification/drawing conclusions, Searching for the meaning of the data collected by looking for relationships, similarities, or differences to conclude answers to the problems being studied.

\section{Results and Discussion}

The results of this study were obtained from interviews with pre-determined sources as sources of information for this study. After that, data reduction was carried out from the interview results by making interview transcripts and then making an analysis table in coding to find the findings of the case studies in this study. The findings are changed in summary with standard language. From the results of interviews that have been carried out, researchers get information about the implementation of the Business Road Map at the Café Room Meeting. Presentation of the results of the interview in the form of a description of the implementation of the Business Road Map (BRM), namely the development of the Business model Canvas (BMC), which is currently a relatively new business model and only a few SMEs use it, one of which is the Temu Room café. The following are the research results that have been summarized sequentially according to the variables that have been determined.

The Ruang Temu is one of the cafes engaged in the culinary field by using a productive cafe, a place for learning, meetings, and other events. In addition to providing several food and beverage products, such as cafes in general, the difference here is that the Ruang Temu Caféhas business DNA makes it easy to see the added value of the cafe.

The Temu Room Cafe was founded in Samarinda by Mrs. Windi Karina Fatmawati in mid-2019. Before becoming a Temu Room Cafe, a cafe was also established, namely Tawon Cafe, but it did not last long, only about one year, and then it was taken over by Windi's mother. The Ruang Temu Café has been established for approximately two years and is considered stable because it can still survive, especially amid the COVID-19 pandemic. Initially, the Ruang Temu Caféused the Business Model Canvas strategy because the business was temporarily stuck from all the main pillars of the Business Model canvas implemented, and there were no results. So that the cafe owner was confused about the continuation of the Business Model Canvas because all the strategies had been tried to implement, but there was also no change from his business. Finally, in early 2020, after getting to know the Business Road Map, the Ruang Temu Cafétried to implement the Business Road Map in the Cafe Ruang Temu. Over time, coupled with the increasing Covid-19 outbreak, there was a significant decline in turnover. It is not enough to stop there; the policy requires a lockdown so that the Ruang Temu cafe was closed for four months without visitors and any income. Then after the government issued a policy in the New Normal era, the Ruang Temu cafe reopened by creating a new strategy for new target markets, new promotions, switching from offline to online. With the end of the lockdown era into the New Normal era, the Temu Room Cafe had to be revised again with the Business Roadmap tools to finally get a health protocol certification from the health department, from the ministry of health, and finally from the governor to be implemented at the Temu Room Cafe. Then the implementation in the field found that after implementing the new Business Road Map, there was an increase in turnover, which increased rapidly by implementing the Business Road Map combined with the New Normal era.

From the many cafes scattered in Samarinda, we can conclude that the business opportunity or cafe business in Samarinda is indeed quite promising because most millennials need a gathering place and a place other than at home, especially in some circles such as students, workers, and others whether it is a regular event or events such as seminars and office meetings. However, most often, it is a business training and what makes it different is that the Ruang Temu Cafe provides a place and mentors and materials for free.

In the business model strategy, the Business Model Canvas is defined as a tool for business mapping how the business can run and develop. The Business Road Map itself is a business model strategy resulting from developing the Business Model Canvas. Several MSMEs have used the Business Roadmap in several cities in Indonesia because it is considered to have many benefits for MSMEs. However, the business model is considered lacking because there are still unresolved problems.

The Business Model Canvas or BMC is usually used as a business mapping for business development. Apart from being a business mapping, it can also be used as a business check-up. Business check-ups allow us to view or check the health of our business. So we can conclude the shortcomings of our business by looking at the indicator columns in the Business Road Maptools or BRM. However, after discovering the Business Road Map or BRM, the business model is assessed in more detail if applied to our business. The Business Road Map or BRM was first discovered and introduced by coach Ridwan Abadi. Coach Ridwan Abadi is a business coach and a business practitioner who has years of experience building various businesses. Then, coach Ridwan Abadi found a Business Road Map to cover the shortcomings in the Business Model Canvas or BMC. Some MSMEs try to dissect and study the Business Road Map or BRM tools to conclude that the results are significant and some MSMEs feel helped by this Business Road Map or BRM. 
According to previous research, it can be explained that there are many business models, and these business models can still be developed, as is the case with the business model developed into the Business Model Canvas. And then, the Business Model Canvas will be developed into a Business Road Map. There are several tools Business Road Map or BRM.

1. Goals; Goals are goals or the achievement of a targeted turnover within a certain period that has been set in detail. Starting from a year, a month, a week, to a day. The purpose of making it is so that business actors have a target or turnover achievement to pursue in running a business.

2. Reality; Reality is a breakdown of the difference in the turnover target that will be obtained if the business is running to catch up with the difference in the nominal turnover obtained. The goal is for business people to know how achieving business turnover is to see its lack.

3. Definition; Business needs are arranged in order to achieve business goals. The definition of a business that will be compiled is to generate cash by helping people sell a product or service. The purpose of making a definition is to explain what the definition of a business is and what problems a business can solve so that business has a reason to grow and develop even better.

4. Target Market; The target market is potential buyers who must get information and promotion related to the product. This means that they need to take the proper steps to reach consumers well. The end goal is to make consumers buy the product. The target market aims to ensure that marketing is right on target.

5. Leverage; Leverage or influence is anyone from any group and circle of influence to increase visitors or consumers. Leverage aims to see who and from which groups have the potential greatest to bring customers or consumers to buy our products.

6. Additional Value; Additional value describes or describes the value or excess of the goods we sell with competitors' goods. What products (goods/services) will you sell? What are the advantages of the product are going to sell compared to existing products? The goal is to provide added value or use value of an item to our products so that the products we sell become more valuable.

7. Competitors Analysis; Competitors Analysis is an activity in which the seller or business actor analyzes the strengths and weaknesses of the Competitors or competitors as a reference to win the competition. The goal is that business actors can easily find out the strengths and weaknesses of their competitors and use them as reference material to evaluate our business so that our business becomes better than competitors without bringing down competitors' businesses.

8. Distribution; Distribution is the distribution process from producers to consumers or getting customers to get our products online and offline. Distribution aims to facilitate the buying and selling process between business actors and customers by creating a system or media connecting the two parties.

9. Funnelling; Funneling is the process of getting customers to understand our products and why our products are of high value so that customers will come into our business or buy our products. The purpose of funneling is to bring in more consumers or customers by filtering or directing from groups, be it students, the public, or employees who have more significant potential to come to the business we run.

10. Customer Relationship; Customer relationship is an effort made by business actors to retain existing customers by establishing solid bonds between customers and business actors. The goal is to build and maintain a strong relationship between business actors and customers or consumers to enable customers to come again and buy our products.

11. Income Stream; Income Stream is a type of generated income, whether generated online or offline, or online and offline. The goal is to find out the sales system in our online or offline business so that it will be easier to develop a suitable business strategy for our business in the future.

12. Activity; Business activities must be carried out to run optimally, whether operational, marketing, finance, or HR. The goal is to create a good management team and create what activities should be carried out to improve our business.

13. Skills; The types of abilities must be possessed so that our business can continue to run, both operational and nonoperational. It aims to see abilities that we do not have that we must have and learn to run well.

14. Resources; Resources are the types of assets and goods and materials that we must have to run a business. It aims to prepare what goods and assets we must have before we run a business.

15. Partner; Partners are colleagues or supporting tools to run, be it a tool supplier or raw material supplier. It aims to prepare partners or partners, whether equipment or assets or suppliers' raw material, making it easier for us to run a business later.

16. Cost Structure; Cost Structure is a breakdown of all types of costs generated in running a business, be it Cost of Goods Sold, raw materials, and others. It aims to find out in more detail all costs generated when running a business to avoid discrepancies or miscalculations. 
After conducting a business mapping interview using the Business Model Canvas and related to implementing the Business Road Map at the Temu Room Cafe, the next stage is observation, which is to see how far the development of the business model is and how the results are after the implementation of the Business Road Map at the Cafe Ruang Temu. For implementing the Business Road Map in the cafe Ruang Temu, first when problems or difficulties are encountered. If turnover is stuck, we have to look at the column located on the right, how the implementation is by what want, and whether there are obstacles that are being faced. These columns are target market, leverage, additional value, competitor analysis, distribution, promotion, funnelling, customer relations, and income stream.

1. Target Market; Based on the research results on the Target Market elements, ensure that marketing is right on target. Forage, namely the age of 20-24 years with the target of men and women for education, namely higher education with the middle segment and the target of professional workers, entrepreneurs, and students. For the city's geography, behaviour or habits are intended for meetings, socialization, work, reading books, enjoying coffee, and others. For user status or frequent customers, it is intended for regular and loyal customers. For needs, it is intended as a symbol of expression of urban lifestyles, as an excellent place for coffee and socializing, a place for meeting/learning, sharing, and discussion. The Ruang Temu customers are suitable for the target market because, on average, entrepreneurs and students usually want to study or relax.

2. Leverage; Based on research on the Leverage element or anyone who affects increasing visitors or consumers. Several organizations are considered capable of increasing visitors or consumers. Students, campus organizations, offices or agencies, business communities, business owners, and the general community are among them. For leverage, it is considered appropriate. Some influential people in increasing visitors at the Cafe Ruang Temu, such as students, campus organizations, offices, or agencies in question, are some of the groups mentioned that have the potential to hold events at the Ruang Temu Caféso that they have the potential to bring in more visitors to join the event-and visiting the Ruang Temu Caféas well as other events.

3. Additional Value; Based on the research results on the Additional Value element or Added Value, we describe the value or excess of the goods we sell. Comfortable, quiet, for meetups, can be used for learning, productive cafe concepts. The Ruang Temu Caféhas worked as a productive cafe for additional value, comfortable and quiet, and not infrequently used as a meetup place.

4. Competitors Analysis; Based on the research results on the elements of Competitors Analysis or how to analyze the strengths and weaknesses of the Competitors or competitors. In terms of strength or strength, the Ruang Temu Cafe lives in the middle of the city, already has a programmer community, there is already a meeting place, a good place has several rooms, and has excellent furniture that aims to be one of the attractions of the Temu Room Cafe. For weakness or weakness is the high cost, and the calculation of the rate is calculated hourly. Then for the opportunity, namely the opportunity is still good, the place is still better than similar cafes, and has the quality of competitors. There are several threats or threats, namely the parking area is not wide enough, and the furniture/facilities are still lacking. It is also considered appropriate for competitor analysis, but several weaknesses are found, namely the parking area is not wide enough, and the furniture/facilities are still lacking.

5. Distribution; Based on research results on the distribution element or the distribution process from producers to consumers. The first is through the Ruang Temu Cafe itself; the second is through gofood, the second is through grab food, the third is through online couriers, and the last is via godsend or colony cards. During the covid-19 pandemic, online distribution was quite effective, considering that it was impossible to receive more customers due to restrictions imposed by the government, so they had to be distanced.

6. Funnelling; Based on the research results on the elements of Funneling or the process of bringing customers into our business or buying our products. The Ruang Temu Cafe carries out two options. The first is creating content or creating business education, which aims to attract people to study at the Ruang Temu Cafe and pnter prenuer or discuss changing the business. Then the second is through online media, namely Facebook, Instagram, Fanepage, Google Business, and offline media, namely banners, billboards, and brochures. The route is quite active for funnelling, as seen from his social media accounts, which are consistent in creating content, so there are always regular posts for his social media accounts.

7. Customer Relationship; Based on research results on elements or efforts, establishing solid bonds between customers and business actors. There are several ways to do it: making member/colonial cards, making discount promos, making vouchers, creating a reward system, and holding gatherings. For the relationship with customers, the route is quite active. It is also considered appropriate, judging from the several types of promotions offered to customers who often visit the Ruang Temu Caféquite.

8. Income Stream; Income Stream is a type of income stream generated whether income or income is generated online, offline, or online and offline. The goal is to find out the sales system in our online or offline business so that it will be easier to develop a suitable business strategy for our business in the future. The income stream is also appropriate so that the income stream generated is online and offline. There are no online problems; it is just that we have to be more

Page | 94 
active in making promos and exciting content on social media, then offline when there is a pandemic, so that income is reduced offline or when we eat out.

Then after it was felt that there was no problem with the turnover, and it turned out that the turnover was good, but the margin was not visible, there is a problem in the left column. So what must be done is to look at the column located on the left, how the implementation is by what is desired and whether there are obstacles that are being faced. Some of these columns are activities, skills, resources, partners, and cost structure.

9. Activity; Based on the results of research on the elements of Activity or what business activities must be carried out so that business runs optimally. Namely, collecting a database of target markets, collaborating with market levers, analyzing markets, promoting distribution, building customer relationships, and producing added value. Some of the efforts made by the Ruang Temu Caféare pretty appropriate, namely collecting databases, market levers, market analysis, distribution promotion, building customer relationships, and producing added value. Usually, Cafe Ruang Temus often holds several seminar training events and several promotions through offline channels by making banners. And brochures. Moreover, for online, namely creating promotional content on social media owned by the route.

10. Skill; Based on the research results on the Skill element or type of what ability must be possessed so that the business can continue to run well. His skills are bar and kitchen production skills, HR management skills, service excellent skills, marketing and promotion skills, and financial expertise. Several divisions, be it production, HR, marketing, and finance, were created separately, and some of the selected ones have expertise in their fields and respect for their management. This corresponds to the BRM column that has made its function to allow each organizer to focus on fields of respect so that businesses can run around and thrive.

11. Resource; Based on research results on Resource elements or types of assets and goods and materials we should have. Types of assets and goods that must be owned are capital/financial, human (which consists of 4 baristas, three kitchen staff, one office boy, one sales division, and one person serving as admin), then place, raw materials, and equipment. The Resource column is also deemed appropriate; in this case, the Ruang Temu has several people appointed as employees or people who play a role. The Ruang Temu Cafécan carry out its activities that also have their respective expertise in their fields.

12. Partners; Based on our research at the element, Partners or colleagues are support tools for the business going well. Partners consist of capital provided by investors, humans, namely employees, places, namely shop owners, raw materials, namely suppliers, and equipment, namely suppliers. In the column, it is also appropriate. In running its business, the Ruang Temu Cafémust also have several trusted partners, both suppliers of raw materials, equipment, and shop owners, so that the Ruang Temu Cafédoes not have trouble finding raw materials and equipment. When there is a problem, it will not be challenging to finish it.

13. Cost Structure; Based on research results on Cost Structure elements or details of all types of costs generated in running a business. For details on the types of costs generated, capital from investors and using a profit-sharing system, space rental costs, raw material costs, costs of goods sold, equipment costs, and water and electricity costs. The cost Structure column is also still controlled so that it is still by the existing column. Several costs must be incurred, such as routine expenses every day, namely the purchase of raw materials, then routine expenses every month, to expenses every year so that the Ruang Temu Cafécan continue to operate.

After researching the Business Road Map at the cafe Ruang Temu, it was found that there was a significant increase in turnover after implementing the Business Roadmap. However, it was down because of the Covid-19 pandemic, which at that time required all business actors to temporarily lockdown; after the situation returned to normal, the Ruang Temu Caférose again with a new Business Road Map strategy with slight modifications, namely by implementing health protocols in the new average era and obtaining protocol certification. Health from the government. Surprisingly, after getting up and reengineering the Cafe Ruang Temu, it was a success with its strategy, turnover increased again, and reservation requests were getting busier in a short time. The Business Road Map, which is a development of the Business Model Canvas, has several pillars that are much more detailed than the pillars of the Business Model Canvas.

Then after doing research, the researchers found some advantages and disadvantages of the Business Road map. The advantages of the Business Roadmap are that it is more detailed in looking at the shortcomings of the business and in seeing the health of the business; the goal is to make it easier to build marketing strategies, more accessible to get new market share, more straightforward to determine target markets, easier to determine distribution, and can also be used as a business health check-up. So BRM can see if there are problems, whether in income, expenses, promotions, or managerial terms. While the weakness is that it is not applicable at the initial development stage of the business, cannot survive in every condition so that it requires reengineering or changes to business strategy, cannot develop if one of the pillars experiences obstacles or problems so that it requires solving the problem so that it can get back running. 
The difference between the Business Model Canvas and the Business Road Map lies in its use. The Business Model Canvas is used as a business mapping, while the Business Road Map is not only a business mapping; it can also be used as a business check-up or a business health check. It is more structured, detailed; then can see what strategies need to be used.

\section{Conclusion}

According to the results of several previous studies, the Business Model Canvas experts can still be further developed into a Business Road Map so that the business mapping becomes more focused and more detailed. According to experts, it is the basis and contains the object of research. Business Model Canvas (BMC) is one of the strategic tools used to describe a business model and describe the rationale for how an organization creates, delivers, and captures value. Meanwhile, a Business Roadmap is a pattern or Business Mapping Method to build a business model/business plan that can create growth over time.

After researching the Business Road Map at the cafe Ruang Temu, it was found that there was a significant increase in turnover after implementing the Business Roadmap. The actual Business Road Map is a development of the Business Model Canvas. The Business Roadmap has several pillars that are much more detailed when compared to the pillars of the Business Model Canvas. The difference between the Business Model Canvas and the Business Road Map lies in its use. The Business Model Canvas is used as a business mapping, while the Business Road Map is not only used as a business map; it can also be used as a business check-up or a business health check. The Business Roadmap is very suitable for all types of business, especially for MSMEs. Compared to other business models, the Business Road Map is considered to be much more detailed in business mapping and can also check the business's health. It is also easier for us to analyze the business that we will run.

\section{References}

[1] ALFARISI, A. (2019). Perumusan Strategi Business Model Canvas (BMC) pada Perusahaan Sandal Toyosima Singosari. Jurnal Ilmiah Mahasiswa FEB, 7(2).

[2] Azis, E., \& Pratama, R.P. 2018. ANALISIS MODEL BISNIS DENGAN PENDEKATAN BUSINESS MODEL CANVAS (Studi Kasus MxD). Universitas Telkom.

[3] Chandra, D. (2016). Model bisnis pada perusahaan X menggunakan business model canvas. Agora, 4(1), 18-25.

[4] Fritscher, B., \& Pigneur, Y. (2015, July). Extending the business model canvas: A dynamic perspective. In Proc. International Symposium on Business Modeling and Software Design (Vol. 5, pp. 86-96). ScitePress.

[5] Alperdo, T. D., \& Gata, G. (2019). IMPLEMENTASI E-COMMERCE MENGGUNAKAN BUSINESS MODEL CANVAS DAN IFML PADA DISTRO MR BRO. IDEALIS: InDonEsiA journaL Information System, 2(6), 369-376.

[6] Lüttgens, D., \& Diener, K. (2016). Business model patterns used as a tool for creating (new) innovative business models. Journal of Business Models, 4(3).

[7] Herawati, L. et al. 2019. Penerapan Bisnis Model Kanvas Dalam Penentuan Rencana Manajemen Usaha Kedelai Edamame Goreng. Universitas Jember.

[8] Maddinsyah, A., Hidayat, D., Juhaeri, J., Susanto, D., \& Sunarsi, D. (2020). Desain Formulasi Dan Implementasi Bisnis Strategik Dengan Pendekatan Business Model Canvas (BMC) Terintegrasi Kerangka Integrated Performance Management System (IPMS) Pada Koperasi Asperindo. Inovasi, 7(2), 67-76.

[9] Solihah, E., Hubeis, A. V. S., \& Maulana, A. (2014). Analisis model bisnis pada KNM fish farm dengan pendekatan business model canvas (BMC). Jurnal Sosial Ekonomi Kelautan dan Perikanan, 9(2).

[10] Kusriyanti, T. (2020). PERANCANGAN STRATEGI BISNIS DENGAN METODE BUSINESS MODEL CANVAS PADA LEORA DESIGN INTERIOR \& FURNITURE. JURNAL MANAJEMEN PENDIDIKAN DAN ILMU SOSIAL, 1(2), 527-536.

[11] Herawati, N., Lindriati, T., \& Suryaningrat, I. B. (2019). Penerapan bisnis model kanvas dalam penentuan rencana manajemen usaha kedelai edamame goreng. Jurnal Agroteknologi, 13(01), 42-51.

[12] Luthan, M. Z., Winandi, R., \& Rifin, A. (2019, October). ANALISIS PENGEMBANGAN MODEL BISNIS KANVAS PERUSAHAAN HORTIKULTURA PT. XYZ. In Forum Agribisnis: Agribusiness Forum (Vol. 9, No. 2, pp. 185-199).

[13] Remane, G., Hanelt, A., Tesch, J. F., \& Kolbe, L. M. (2017). The business model pattern database-a tool for systematic business model innovation. International Journal of Innovation Management, 21(01), 1750004.

[14] Kosasi, V. M., 2015. Analisis dan evaluasi model bisnis pada pantai seafood restaurant dengan pendekatan Model Business Canvas. Universitas Kristen Petra.

[15] Malasari. (2019). Perancangan Business Model Canvas Pada Jessen Cake Samarinda. Universitas Mulawarman.

[16] Mardiansa, F. 2017. IMPLEMENTASI BUSINESS MODEL CANVAS SEBAGAI ALTERNATIF STRATEGI BISNIS DALAM PENGEMBANGAN INDUSTRI KREATIF (Studi Kasus Pada Usaha Papan Bunga Dian Florist Bandar Lampung). Universitas lampung.

[17] Meranga, I. S. (2019). IMPLEMENTASI BUSINESS MODEL CANVAS PADA PERUSAHAAN SOSIA. JURAKUNMAN (JURNAL AKUNTANSI DAN MANAJEMEN), 12(2).

[18] Narto, N. (2017). PENGEMBANGAN BISNIS MODEL UNTUK MENINGKATKAN DAYA SAING INDUSTRI BATIK SUMENEP MADURA. Prosiding SNST Fakultas Teknik, 1(1).

[19] Harfiani, R., \& Pasaribu, M. (2019, October). Implementasi Business Model Canvas Pada CV. Media (Penerbit dan Distributor Buku Pelajaran PAUD). In Prosiding Seminar Nasional Kewirausahaan (Vol. 1, No. 1, pp. 200-208).

[20] Putra, A. F. P. (2020). Strategi Pengembangan Model Bisnis Klaster Industri Tomat Krispi Daumato Berdasarkan Analisis SWOT dan BMC. Journal of Industrial View, 2(1), 33-42. 
[21] Rosello. 2019. Study of Strategic Drivers and Pattern that Change Planet's Business Model Canvas. Universitat Politecnica De Catalunya.

[22] Tulus, R. 2016. Deskripsi Model Bisnis Pada PT Joyo Bekti Indah Menggunakan Business Model Canvas. Universitas Kristen Putra.

[23] Bagindo, M. P., Sanim, B., \& Saptono, T. (2016). Model bisnis ekowisata di taman nasional laut Bunaken dengan pendekatan business model canvas. MANAJEMEN IKM: Jurnal Manajemen Pengembangan Industri Kecil Menengah, 11(1), 80-88.

[24] Saputra, A. D. D., \& Widjaja, A. (2019). IMPLEMENTASI SISTEM PENJUALAN ONLINE BERBASIS E-COMMERCE MENGGUNAKAN BUSINESS MODEL CANVAS PADA COSY DISTRO. IDEALIS: InDonEsiA journaL Information System, 2(5), 9-15.

[25] Sari. 2019. Strategi pengembangan Model Bisnis Dengan Menggunakan Pendekatan Triple Layer Business Model Canvas. Universitas Pendidikan Indonesia.

[26] Fatricia, W., \& Sultan, M. A. S. (2019). Implementasi Bisnis Model Kanvas dalam Perancangan Manajemen Bisnis Aplikasi JASKOST. Jurnal Ilmu Manajemen dan Bisnis, 10(1), 93-100.

[27] Sultan, R., \& Hasbi, I. (2018). Analisis Bisnis Model Kanvas pada Kadatuan Koffie Bandung. Almana: Jurnal Manajemen dan Bisnis, 2(2), 116-123.

[28] Tantriana, D. (2018, October). BUSINESS MODEL CANVAS PRODUK SIMPANAN KENCLENG KOPERASI SYARIAH MANFAAT SURABAYA. In Prosiding Seminar Nasional: Manajemen, Akuntansi, dan Perbankan (Vol. 1, No. 1, pp. 154-169).

[29] Warnaningtyas, H. (2020). Desain Bisnis Model Canvas (BMC) Pada Usaha Batik Kota Madiun. JURNAL EKOMAKS: Jurnal Manajemen, Ekonomi Kreatif dan Bisnis, 9(2), 52-65. 